This is an author produced version of a paper published in FOREST POLICY AND ECONOMICS. This paper has been peer-reviewed and is proof-corrected, but does not include the journal pagination.

Citation for the published paper:

Nordström, E-M, Eriksson, L. O. \& Öhman, K. (2010) Integrating multiple criteria decision analysis in participatory forest planning : experience from a case study in northern Sweden. Forest Policy and Economics. Volume: 12 Number: 8, pp 562-574. http://dx.doi.org/10.1016/j.forpol.2010.07.006

Access to the published version may require journal subscription. Published with permission from: Elsevier

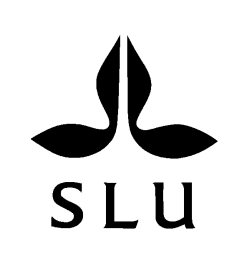

Epsilon Open Archive http://epsilon.slu.se 


\title{
Integrating multiple criteria decision analysis in participatory forest planning: Experience from a case study in northern Sweden
}

\author{
Eva-Maria Nordström $^{\mathrm{a}}{ }^{*}$, Ljusk Ola Eriksson $^{\mathrm{a}}$, Karin Öhman ${ }^{\mathrm{a}}$
}

${ }^{a}$ Department of Forest Resource Management, Swedish University of Agricultural Sciences, 90183 Umeå, Sweden

* Corresponding author. Tel.: +46 90786 8258; fax: +46 90778116.

E-mail address: eva-maria.nordstrom@srh.slu.se (Eva-Maria Nordström) 


\section{Abstract}

Forest planning in a participatory context often involves multiple stakeholders with conflicting interests. A promising approach for handling these complex situations is to integrate participatory planning and multiple criteria decision analysis (MCDA). The objective of this paper is to analyze strengths and weaknesses of such an integrated approach, focusing on how the use of MCDA has influenced the participatory process. The paper outlines a model for a participatory MCDA process with five steps: stakeholder analysis, structuring of the decision problem, generation of alternatives, elicitation of preferences, and ranking of alternatives. This model was applied in a case study of a planning process for the urban forest in Lycksele, Sweden. In interviews with stakeholders, criteria for four different social groups were identified. Stakeholders also identified specific areas important to them and explained what activities the areas were used for and the forest management they wished for there. Existing forest data were combined with information from interviews to create a map in which the urban forest was divided into zones of different management classes. Three alternative strategic forest plans were produced based on the zonal map. The stakeholders stated their preferences individually by the Analytic Hierarchy Process in inquiry forms and a ranking of alternatives and consistency ratios were determined for each stakeholder. Rankings of alternatives were aggregated; first, for each social group using the arithmetic mean, and then an overall aggregated ranking was calculated from the group rankings using the weighted arithmetic mean. The participatory MCDA process in Lycksele is assessed against five social goals: incorporating public values into decisions, improving the substantive quality of decisions, resolving conflict among competing interests, building trust in institutions, and educating and informing the public. The results and assessment of the case study support the integration of participatory planning and MCDA as a viable option for handling complex forest-management situations. Key issues related to the MCDA methodology that need to be explored further were identified: 1) The handling of placespecific criteria, 2) development of alternatives, 3) the aggregation of individual preferences into a common preference, and 4) application and evaluation of the integrated approach in real case studies. 


\section{Keywords}

Analytic Hierarchy Process; Decision support; Forest management planning; Public participation; Stakeholders

\section{Introduction}

Forest planning is a process that involves a sequence of activities, ideally starting with decision problem recognition and ending with a forest plan. Involving the public in the planning process would allow for public values to influence the outcome. Basically, participation can be used to increase the legitimacy of a decision and to facilitate implementation, as well as to improve the substantive quality of the decision in terms of total social benefit. In addition, participation can be an end in itself, fulfilling democratic or other local empowerment objectives (Buchy and Hoverman, 2000).

However, participatory forest planning can be a complicated and delicate task. The complexity springs from, e.g., the facts that several stakeholders are involved and that these stakeholders very often have conflicting interests; that is, the situation has both a multiple stakeholder and a multiple criteria character. The delicate task is to make the participatory process legitimate and accepted by stakeholders, because the stakeholders may have very different expectations of a participatory process (Kangas et al., 2010; Webler and Tuler, 2001).

One promising approach for handling the complexity is by structuring the planning process with multiple criteria decision analysis (MCDA) (Mendoza and Martins, 2006). Although MCDA is basically a decision analysis tool for single decision-maker situations, the multi-criteria character also makes MCDA potentially useful as a tool for participatory planning. Belton and Stewart (2002) describe MCDA as a process that seeks 1) to integrate objective measurement with value judgment and 2) to make explicit and manage subjectivity. The process has three key phases:

1. Problem identification and structuring

2. Model building and use

3. Development of action plans 
Furthermore, Belton and Stewart (2002) also define MCDA as “an umbrella term to describe a collection of formal approaches which seek to take explicit account of multiple criteria in helping individuals or groups to explore decisions that matter”. The formal approaches mentioned by Belton and Stewart will hereafter be referred to as "MCDA techniques”. These mathematical techniques are used to elicit preferences for criteria and alternatives and to synthesize the preference information into some kind of ordering of alternatives according to merits, given the preferences. The Analytic Hierarchy Process (AHP), Multiattribute Utility Theory, and ELECTRE are examples of MCDA techniques that have been used in a forest planning context (Ananda and Herath, 2003b; Diaz-Balteiro and Romero, 2008; Kangas et al., 2001; Pykäläinen et al., 1999). The choice of technique is central to how the phase of model building and use is conducted in the MCDA process, but it will most likely also influence the problem identification and structuring phase and the development of action plans. Moreover, the problem identification and structuring phase should guide a choice of MCDA technique to suit the decision problem in question.

A principal benefit of MCDA, compared with many other tools for participatory planning, is that MCDA provides a structured way of working that generates knowledge about the problem and about the objectives of the different stakeholders (Mendoza and Martins, 2006). Furthermore, MCDA can support a participatory process in making it transparent, fair, and understandable, which are all important properties for the process to be considered legitimate and accepted by the stakeholders. Transparency means that it is possible to account for the outcome of the process in terms of the input and the mechanisms of the MCDA technique, because the MCDA process is well structured (Rauschmayer and Wittmer, 2006). Fairness has to do with the power relations between stakeholders and how power differences are handled in the process (Phillips, 1997). With MCDA, the influence of different stakeholders on the outcome can be made explicit in the aggregation of preferences. However, MCDA techniques are in a greater or less degree complicated in the elicitation of preferences, calculations of outcomes, and aggregation of preferences. To choose an appropriate MCDA technique and to explain this technique pedagogically to stakeholders is very important to make the MCDA process understandable; otherwise, MCDA could be a problem rather than a support for the participatory process (Kangas and Kangas, 2005).

In the forestry context, approaches combining participatory planning/group decision making and MCDA are relatively new (Diaz-Balteiro and Romero, 2008), though studies of participatory forest planning in combination with MCDA techniques have been published during the past decade (e.g., Ananda and Herath, 2003a, b; Kangas et al., 2001; Laukkanen et 
al., 2004; Maness and Farrell, 2004; Pykäläinen et al., 1999; Sheppard and Meitner, 2005). A challenge with combining MCDA and participatory planning is the interdisciplinary and applied character of the work (Munda, 2004). Unfortunately, studies tend to focus on the numerical properties of MCDA techniques, no doubt because studies including MCDA are

highly specialized and require expert knowledge. Nevertheless, there is a need for more focus on the participatory aspect of the studies and for analyses that show how MCDA is actually integrated in the participatory process. As pointed out by Mendoza and Martins (2006), this would mean a shift from the view of MCDA as technical methods for problem solving to the view of MCDA as methods for problem structuring. Hence, thorough evaluations of participatory processes using MCDA that treat outcomes beyond the pure numerical results are needed. Otherwise, it will be difficult to assess what effect the use of MCDA has had on the quality of the participatory process and how successful the approach was.

This paper presents a case study where MCDA was integrated in an actual participatory planning process where the aim was to produce a multiple-use forest management plan. The case study comprises a complete participatory MCDA process: Stakeholder analysis (Banville et al., 1998; Grimble and Wellard, 1997), structuring of the decision problem, generation of alternatives, elicitation of preferences, and ranking of alternatives. Compared to earlier studies with similar scope, i.e., commercial forestry in industrialized countries (e.g., Ananda and Herath, 2003a, b; Pykäläinen et al., 1999; Sheppard and Meitner, 2005), the present study emphasizes the importance of early participation in the phases of problem structuring and development of alternatives. There are studies with focus on problem structuring and implications for participation, but these are mainly set in the context of community forestry in developing countries (e.g., Campo et al., 2009; Mendoza and Prabhu, 2005). The objective of this paper is to analyze strengths and weaknesses of the integrated approach based on results from the case study. The analysis is supplemented by an assessment of the participatory process with focus on how the use of MCDA has influenced the process. The assessment is guided by the five social goals for public participation proposed by Beierle and Cayford (2002).

\section{The participatory MCDA process}

This section describes the theoretical framework of the presented case study, the participatory MCDA process. There are various descriptions of the MCDA process in the 
literature, both for single decision maker situations and for participatory situations; the steps of the process differ in names and numbers among authors (Ananda and Herath, 2003b; Belton and Stewart, 2002; Lahdelma et al., 2000; Maness and Farrell, 2004). In this study, we have used MCDA within a participatory planning process where a discrete number of distinct alternatives, i.e., forest plans, are developed and evaluated. Because of this, our description of the process is as follows: 1) stakeholder analysis, 2) structuring of the decision problem, 3) generation of alternatives, 4) elicitation of preferences, and 5) ranking of alternatives (Fig. 1). Steps 2-5, phrased in various ways, are normally included in a description of the MCDA process in a single decision maker situation. In addition, in this study we have chosen to incorporate stakeholder analysis as the first step in the process to emphasize the importance of a stakeholder perspective in participatory planning (cf. Banville et al., 1998).

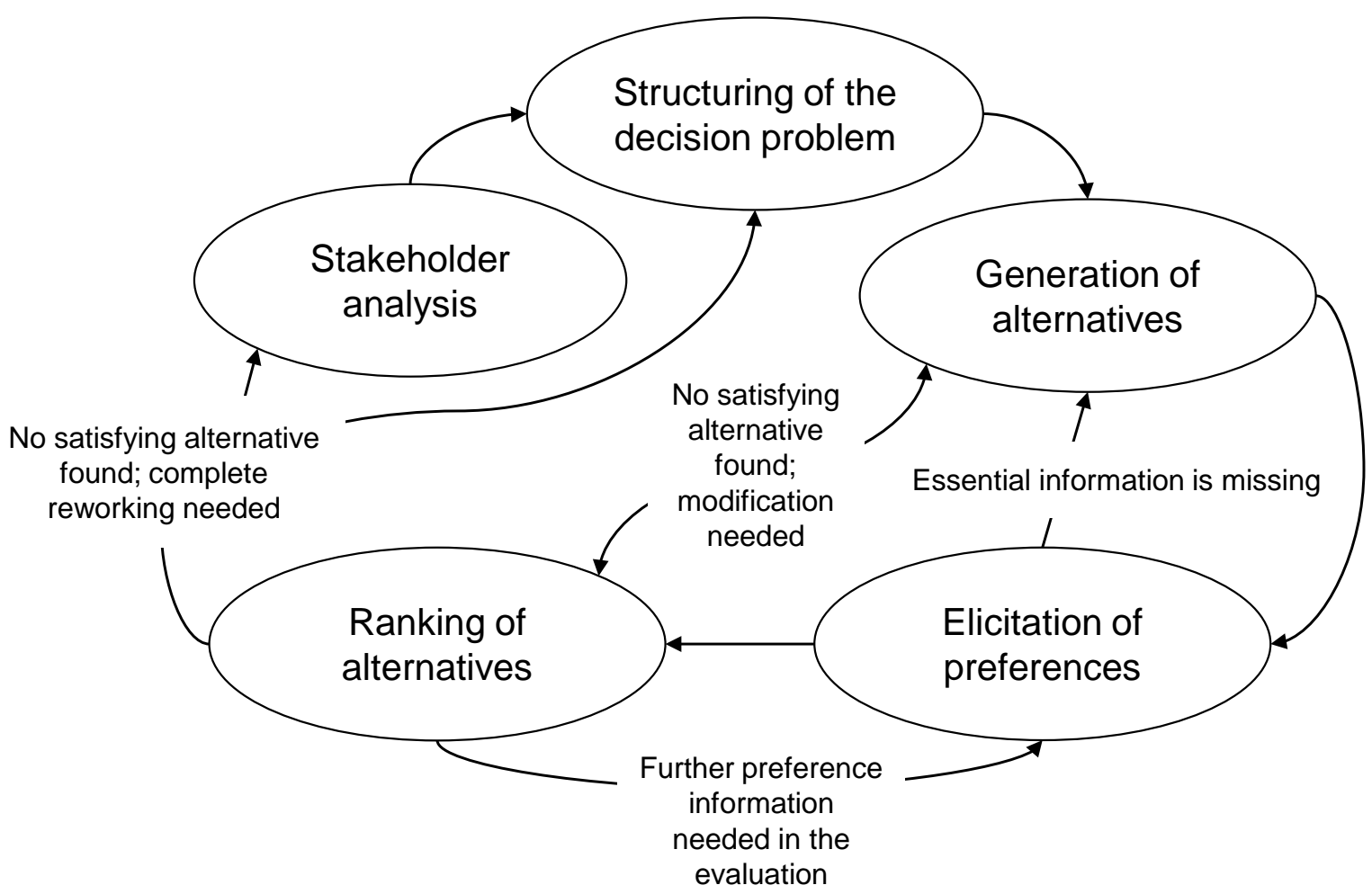

Figure 1. Participatory MCDA process. A general model for the participatory MCDA process contains five phases, which are interconnected.

\subsection{Stakeholder analysis}

The objective of the stakeholder analysis is to identify all relevant stakeholders and to determine the extent of their participation. Stakeholder means someone who is affected by or can affect the situation in some way; that is, the stakeholders have vested interests in the decision problem (Banville et al., 1998). 
A thorough stakeholder analysis is critical at the beginning of a participatory process. If important stakeholders are left out of the process, central questions might be ignored, and consequently the overall picture of the situation will be incomplete. In the end, this can mean that the solution found through the process will not be a solution to the real problem.

Furthermore, a process where central stakeholders are left out is not likely to be accepted as a participatory process, and implementation might be impaired.

The extent of public participation in a decision-making situation can be defined and described using the ladder of participation (Buchy and Hoverman, 2000). The rungs on the ladder of participation represent different levels of participation. The level of participation indicates to what extent the participants have the possibility to influence the participatory process and its outcomes: the higher up the ladder the participants are, the more impact their opinions will have on the final decision. Thus, the participatory ladder defines the relationship among the participants in terms of how power is being redistributed, where power means control over resources and decision-making.

Several ladders of participation, with different numbers of rungs and thus different levels of detail, have been suggested (Arnstein, 1969; Berkes, 1994; Campbell, 1996; Sandström and Widmark, 2007). A simplified version of Arnstein's original ladder of participation, published by the International Association of Public Participation (IAP2, 2007), will be used here as it contains relevant levels that correspond to the use of participation in forest planning situations (Table 1).

Table 1. The International Association for Public Participation's spectrum of public participation

\begin{tabular}{ll}
\hline Level & Public participation goal \\
\hline 5 & To place final decision-making in the hands of the public \\
Empower & To partner with the public in each aspect of the decision including the development of \\
4 & alternatives and identification of the preferred solution \\
Collaborate & To work directly with the public throughout the process to ensure public issues and concerns are \\
Involve & consistently understood and considered \\
2 & To obtain public feedback on analysis, alternatives, and/or decisions \\
Consult & \\
1 & To provide the public with balanced and objective information to assist them in understanding \\
Inform & problems, alternatives, and/or solutions \\
\hline
\end{tabular}

(C) 2007 International Association for Public Participation, www.iap2.org 


\subsection{Structuring of the decision problem}

The aim of this step is to define the decision problem by identifying and structuring the stakeholders' objectives and attributes. In the MCDA context, an objective can be defined as a statement of something that one wants to achieve (Keeney, 1992; Starr and Zeleny, 1977). Moreover, objectives have a preferential direction; that is, they are either of the kind "more is better" or of "less is better". Attributes describes characteristics of the alternatives; i.e., one or more attributes are used to measure how well an alternative performs in terms of a certain objective (Keeney, 1992; Starr and Zeleny, 1977). Criterion is a general term that includes both objectives and attributes (Malczewski, 1999; Starr and Zeleny, 1977); this term will normally be used in this paper. The set of objectives identified for a situation describes the decision problem. Thus, to define the problem properly, it is necessary to find all relevant objectives. In a participatory process, this means that stakeholders must be involved. Furthermore, in some situations, such as forest planning, there are not only general values to consider, but spatial and place-specific values may be at least as important to stakeholders (Kangas et al., 2008). To capture that kind of values, maps are needed when stakeholders are expressing their criteria.

The set of objectives should have the following desirable properties to be useful for defining the problem: they should be essential, controllable, complete, measurable, operational, decomposable, nonredundant, concise, and understandable (Keeney, 1992). The objectives can be structured in an objective hierarchy, a tree-like structure where objectives are organized according to how they relate to each other.

\subsection{Development of alternatives}

The aim of this step is to define or develop alternative solutions to the decision problem. As already mentioned, the MCDA process applied in this study requires a discrete number of alternatives.

How and what kind of alternatives are generated is critical to the outcome of the process, because if alternatives cannot be modified or new ones cannot be added in the process the choice is restricted to a discrete set of alternatives. Often, an iterative process in which alternatives are refined according to stakeholders' preferences would be desirable (see e.g., Castelletti and Soncini-Sessa, 2006), but time and resources constraints can make this unfeasible. Thus, alternatives must be generated carefully; they must be nondominated, realistic, and not too extremely directed toward any single stakeholder's interests, but at the same time, they must span the objective space sufficiently (Hiltunen et al. 2009). Place- 
specific values identified by stakeholders should be considered in the generation of alternatives. Depending on how the alternatives are to be evaluated, the number of alternatives is also important: too many alternatives can make the evaluation by stakeholders too demanding, rendering the final result unreliable.

\subsection{Elicitation of preferences}

The aim of this step is to obtain the stakeholders' preferences for criteria and alternatives in terms of each criterion. Preferences are subjective judgments made by the stakeholders on the importance or value of a criterion or an alternative.

Varying modes of expression can be used when stakeholders state their preferences: in a group or individually, at a personal meeting or by a form, on one occasion or iteratively. The choice of mode and MCDA technique must depend on the situation and the stakeholders (Belton and Stewart, 2002; Kangas and Kangas, 2005). In cases where more-complex MCDA techniques are used, a personal meeting with possibilities to adjust preferences as knowledge of the situation increases would be a desirable working mode (Kangas and Kangas, 2005). In situations with many stakeholders, and where actual meetings are made difficult by geographical distance or lack of time, preferences may have to be elicited through inquiry forms or Internet-based, user-friendly decision support systems (Kangas and Store, 2003).

\subsection{Ranking of alternatives}

In the final step, preferences in the form of weights for criteria and alternatives are combined by some kind of decision rule resulting in global priorities for the alternatives. The global priorities are overall weights that make it possible to rank the alternatives in a preference order. The decision rule is defined by the specific MCDA technique used (Malczewski, 1999).

In a group decision-making context, individual preferences must be brought together in some way in order to obtain a group preference. How this is done is both a practical and a philosophical issue. Belton and Pictet (1997) have defined three general procedures for achieving a group decision: 1) sharing - the group can act as a single decision-maker and agree on one common preference; 2) aggregating - the stakeholders can state their individual preferences and a common preference is obtained through voting or calculation; and 3) comparing - the stakeholders state their individual preferences and these are used in a negotiation process where the aim is to find a consensus solution. In the procedures for sharing and comparing, a consensus is sought via discussions and negotiations. When 
aggregation is used, deliberations among stakeholders are replaced by a mechanistic approach to find consensus. Hence, it is important that the method of aggregation is fair and transparent to the stakeholders.

\section{Case study}

The town of Lycksele in northern Sweden is the regional center in a forest landscape area where commercial forestry is an important industry for the local economy. However, the forest around the town holds other values and is important to the inhabitants of the town for purposes other than timber production, e.g., for the reindeer herding industry, for preserving biodiversity, and for recreation, hunting, and fishing opportunities. The existence of several seemingly incompatible interests in the forest is a potential source of conflict. In addition, the forest nearest to Lycksele town is owned not only by the municipality but also by (in some areas) commercial forest companies, the Church of Sweden, and private landowners. To create a comprehensive overview of the forest use and management around the town of Lycksele, the municipality initiated a project with the aim to produce a multiple-use forest management plan. The plan was to be a strategic forest management plan including both timber production and other uses of the forest. The interests involved motivated a long range perspective, in this case 100 years. The plan was to cover a total area around the town of 8637 ha of productive forest divided into 980 forest stands, encompassing 964 ha of municipality forest, 7277 ha forest belonging to three forest companies and the Church of Sweden, and approximately 396 ha of land owned by nonindustrial forest owners. The authors of this paper were charged with the task of designing and leading the planning process. The planning process was designed to be a participatory process modeled on the general description of a participatory MCDA process presented previously. A time line for the process is shown in Fig. 2. 


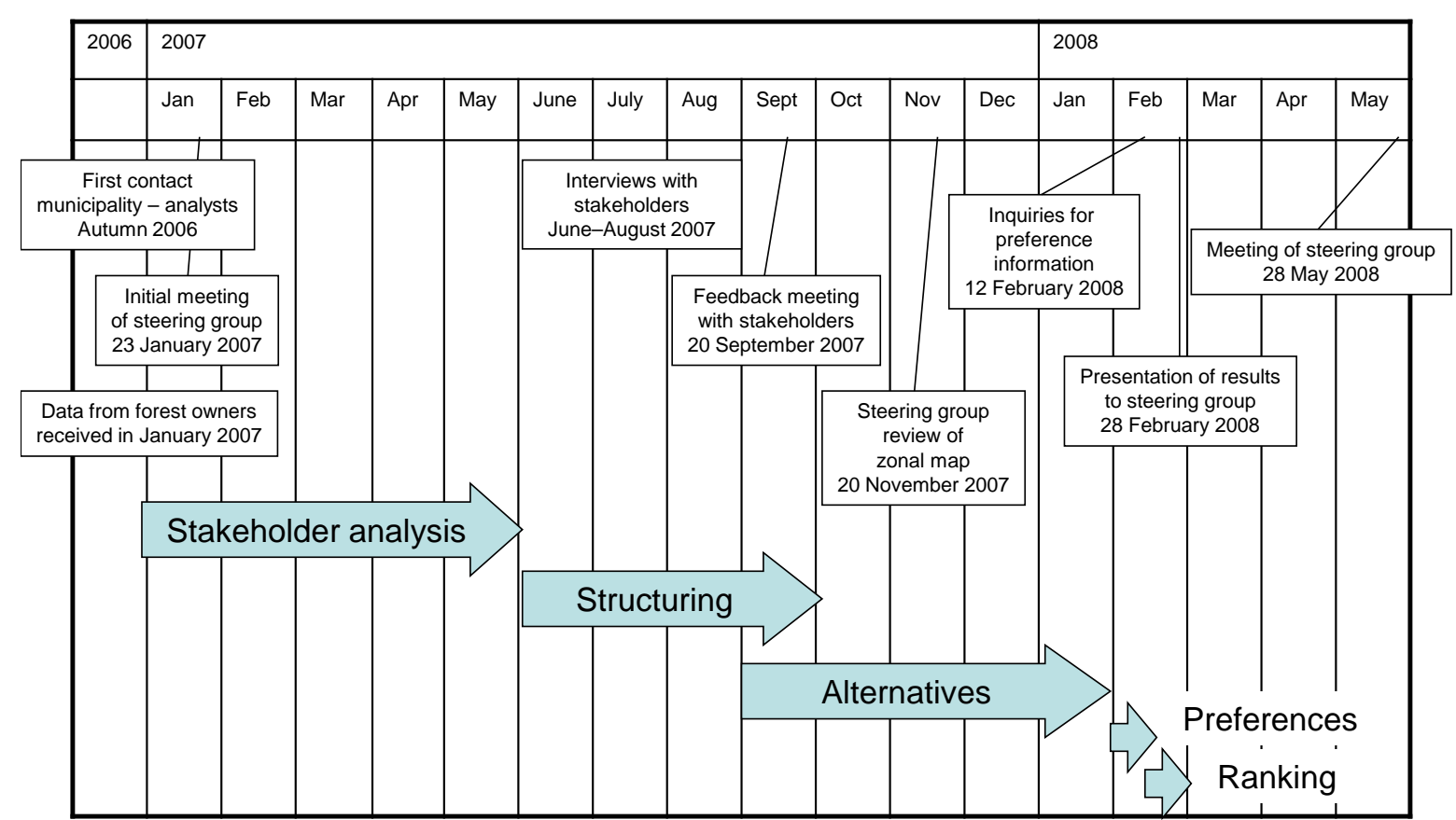

Figure 2. Timeline of the case study process. The timeline shows the activities (in boxes) and phases (block arrows) of the participatory MCDA process in Lycksele.

\subsection{Stakeholder analysis}

The process started with a meeting for representatives from the three forest-owning companies, Church of Sweden, municipality, Forest Agency, County Board, and two of the authors. In this first meeting, these representatives formed a steering group for the planning process. A general outline of the process based on the MCDA-process model was presented by the authors to the members of the steering group, and expectations and apprehensions of the forest owners were discussed. The rest of the meeting was used for two different exercises that formed the basis for the stakeholder analysis.

In the first exercise, the members of the steering group were asked individually to write down potential stakeholders on Post-It notes. The notes were then displayed on a whiteboard. The results were discussed and the proposed stakeholders were grouped according to assumptions of common interests. The stakeholders that were identified were all associations, companies, and other organizations or groups, not individuals.

The purpose of the second exercise was to determine appropriate levels of participation in the planning process. The ladder of participation was presented and briefly explained to the members of the steering group, who were asked to place the different groups of stakeholders on appropriate levels of participation. This task was also done individually, and each member presented and justified his or her suggestion. The results were then discussed by the group 
and a model was created with the desired level of participation for each group of stakeholders. According to this model, the forest owners were to retain the decision-making power, while representatives for nature conservation, outdoor activities, tourism, education, and the reindeer herding industry were placed on the involvement level (level 3 in Table 1). The general public was placed on the consultation level (level 2).

After the first meeting, the list of identified stakeholders was concretized to selected people by the authors, in cooperation with the municipality ecologist. The majority of people selected as representatives for different interests were members of an existing network used by the municipality ecologist as a reference group in forestry-related issues. The grouping of the stakeholders obtained in the exercise with the steering group was simplified into four different groups, hereafter called social groups: timber producers, reindeer herders, recreationists, and environmentalists (Appendix A). A social group was not expected to be completely homogeneous concerning the interests of the stakeholders in the group, but the intergroup disagreements were judged more important than were intragroup disagreements.

Because of the nature of the situation, the number of representatives varied among the social groups. All the forest-owning companies and the municipality were included in the group of timber producers, resulting in five representatives, while there was only one person in the reindeer herders' group (the representative of the reindeer husbandry district of the area). The environmentalists were represented by two people from nongovernmental organizations and one person each from the municipality and the County Board. The recreation group was represented by 14 people; this number was the consequence partly of the existence of many concerned associations and partly of a deliberate act to include many recreationists, because knowledge about the needs of this group in this particular area was insufficient.

\subsection{Structuring of the decision problem}

The next step in the process was to identify criteria for each of the four social groups. The steering group found it important that the stakeholders should express their own criteria. This was done by interviewing the representative stakeholders identified in the stakeholder analysis.

The interviews were semistructured: questions were asked concerning the activities of the stakeholders and their views on the forest and forest management, but the interviews took the form of conversations (see Appendix B for the basic questions) in order to give the stakeholders the opportunity to express their criteria in a natural way as opinions, wishes, and 
needs. The stakeholders were told that the information from the interviews would be used to create a multiple-use forest management plan; that is, they could influence the content of the plan, but the forest owners would not be compelled to adhere strictly to the plan. Many of the stakeholders expressed an understanding of commercial forest management and its role in the local economy, but some stakeholders held the opinion that there should be no timber production in the urban forest. The interviews lasted between 30 and 90 minutes. During the interviews, a form with the basic questions was used to make notes. Maps were used to identify areas of special interest; stakeholders belonging to the recreation, environmentalist, and reindeer herding groups were given maps on which they could mark areas of interest to them and explain why they were important, how they were used, and how they should be managed to benefit the stakeholder's interests. For the forest owners, their forest data in combination with priorities expressed in the interviews served a similar function.

The information from the interviews was used to construct a preliminary objective hierarchy for each of the four social groups. In addition, the maps drawn at the interviews were digitalized as files in ESRI ${ }^{\circledR}$ ArcGIS $^{\circledR}$ Desktop (version 9.2) so that maps showing the areas of interest to the stakeholders of the recreation, environmentalist, and reindeer herding groups could be created. Areas with high biological values set aside for conservation by the forest owners were also included in areas of interest for biodiversity, for the environmentalists. All stakeholders that had been interviewed were invited to a meeting where the hierarchies and the maps were presented for discussion. However, only the steering group, a private forest owner, and one person from the recreationist group attended this meeting. Changes were made to the hierarchies according to opinions expressed in the meeting. The resulting objective hierarchy is shown in Fig. 3. 


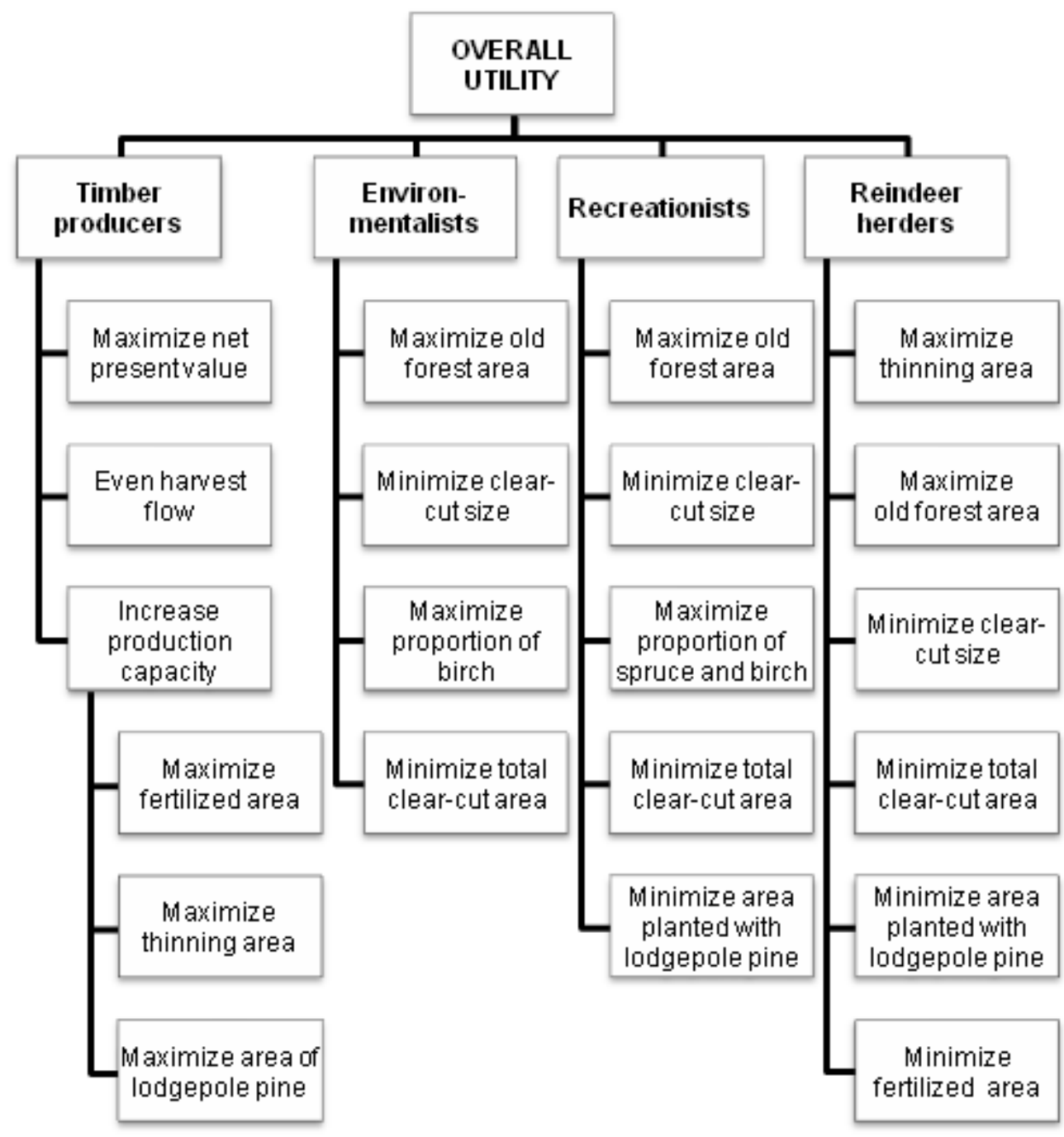

Figure 3. Objective hierarchy for the case study. The criteria were identified in interviews with stakeholders and organized in a hierarchy with the four social groups.

The maps drawn by stakeholders were overlaid with existing information about areas with high biological and recreational values to generate a zonal map on which the forest was divided into four different zones based on what type of silvicultural management should be applied in each zone. The four zones were as follows: 1) zone with no commercial management, 2) zone with no clear-cutting, 3) zone with reinforced consideration to objectives other than timber production, and 4) zone with standard forest management.

The zonal map was sent to the members of the steering group to give them the opportunity to comment and suggest changes. Only minor adjustments were made to the zonal map after this review. The final version of the zonal map is shown in Fig. 4. 
Figure 4. Zonal map for the case study. In the zonal map, the urban forest is divided into four different forest management classes, which are used as inputs in the creation of the three forest plan alternatives. The three zones with adapted management are shown in the map: 1) zone with no commercial cutting, 2) zone with no clear-cutting, and 3) zone with prolonged rotation time. Standard forest management is practiced in the rest of the plan area (zone 4).

\subsection{Development of alternatives}

Based on which zone the stand belonged to, each stand was assigned a treatment class defining the set of allowed treatment schedules ${ }^{1}$. The first treatment class contains stands in zone 1 and buffer zones that are left for undisturbed growth. The second treatment class, defining the treatments in zone 2, contains stands that are never to be clear-cut; instead, a shelterwood of 200 stems per hectare is established. In zone 3, the treatment class contains stands where 20 years are added to the minimum age of final felling in order to prolong the rotation time. Zone 4 contains stands where the full range of standard treatments could be applied. In some stands lodgepole pine establishment could not be accepted because of the stands' characteristics and, in a few cases, restrictions in the Forestry Act. After a stand was assigned a treatment class, the stand data were exported to the GAYA stand simulation system, which simulated all permissible treatment schedules under the given treatment class (Eriksson, 1983; Hoen and Eid, 1990). This resulted in the generation of 116740 schedules, corresponding to an average of almost 100 schedules per stand.

Based on the generated treatment schedules and the identified criteria, three forest plan alternatives were generated with a linear programming model of the Model I type (Johnson and Scheurman, 1977). Each alternative consists of different combinations of treatment schedules for all stands in the landscape, which then results in different values for the criteria in the identified hierarchy. The generation of alternatives was based on compromise programming with the $\mathrm{p}=\infty$ metric (Zeleny, 1982). The aim was to generate realistic alternatives of different directions, without them being too extremely directed toward the interests of any one of the social groups. Balancing these two aspects, and simultaneously restricting the number of alternatives to three, obviously introduces an element of subjectivity in the choice of plans to present to the stakeholders. However, with more than three plans, the

\footnotetext{
${ }^{1}$ A treatment schedule is a sequence of treatments, e.g., regeneration, thinning, and clear-cutting, for a planning unit from period 1 to the end of the planning horizon.
} 
judgment process would have become increasingly complicated for the stakeholders. The alternatives are summarized in Table 2.

Table 2. Summary of alternatives in terms of the attributes

\begin{tabular}{|c|c|c|c|}
\hline Attribute & Plan A & Plan B & Plan C \\
\hline $\begin{array}{l}\text { Net present value, total for all periods (millions of Swedish } \\
\text { crowns) }\end{array}$ & 105.2 & 137.2 & 146.8 \\
\hline Harvest flow & Uneven & Somewhat uneven & Most even \\
\hline \multirow[t]{2}{*}{ Fertilized area, total for all periods (ha), and trend over time } & 5053 & 5178 & 4588 \\
\hline & Even & Even & Decreasing \\
\hline \multirow{2}{*}{$\begin{array}{l}\text { Area of commercial thinning, total for all periods (ha), and } \\
\text { trend over time }\end{array}$} & 6754 & 7802 & 7559 \\
\hline & Even & $\begin{array}{l}\text { Even, with peak in } \\
\text { period } 2\end{array}$ & Decreasing \\
\hline Area of lodgepole pine stands at the end of period 10 (ha) & 2620 & 2632 & 1240 \\
\hline Area of old forest ( $>120$ years) at the end of period 10 (ha) & 2506 & 1431 & 2677 \\
\hline Clear-cut size, average for all periods (ha) & 7.1 & 19.9 & 11.5 \\
\hline Clear-cut area, total for all periods (ha) & 3567 & 6570 & 6470 \\
\hline Percentage of birch, average for all periods (\%) & 3.0 & 2.7 & 3.5 \\
\hline Percentage of spruce, average for all periods (\%) & 8.8 & 9.4 & 10.4 \\
\hline
\end{tabular}

\subsection{Elicitation of preferences}

We asked each respondent to make judgments on the criteria and alternatives by the pairwise comparisons procedure of the AHP. The comparisons were made using the verbal statements of the nine-point scale developed by Thomas L. Saaty (Saaty, 1990) to determine the strength of preference for one criterion or alternative over another. Each respondent was considered a member of one of the four social groups, and they answered questions relating to the criteria for that particular social group. However, the representative for the municipality made judgments on all criteria, because as a local government institution, the municipality is concerned with biodiversity, recreation and reindeer herding; as forest owner, the municipality is also concerned with timber production. Each stakeholder also made pairwise comparisons on the alternatives relating to the set of criteria specific to his or her social group. Attributes for the different alternatives were presented in diagrams and tables as a basis for the judgments. The respondents gave their judgments by filling out inquiry forms sent to them by mail. Five inquiry forms were returned from the timber producers, four from the environmentalists, seven from the recreationists, and one from the reindeer herders. 
The members of the steering group were also asked to make pairwise comparisons of the four social groups to determine the relative importance of each social group. This was done by requesting them to fill out a form sent to them by mail.

\subsection{Ranking of alternatives}

In the final step of the MCDA process, we established a ranking of the alternatives from the preferences expressed by the stakeholders. The starting point was the preferences of each stakeholder in the form of pairwise comparison matrices for criteria and alternatives. Using the standard AHP technique (Saaty, 1990), global priorities for alternatives could be established for each stakeholder, and consistency ratios (CRs) were calculated for each pairwise comparison matrix. The CRs can be found in Appendix C.

A CR of 0.1 , that is an inconsistency of $10 \%$, is the prevalent limit for inconsistency; if the inconsistency is greater, either the stakeholder should reconsider his or her judgments or the original judgments should be improved by the analyst and then presented to the stakeholders for approval (Saaty, 1990). In this case study, the inconsistency was generally high, but there was no opportunity to work iteratively with the stakeholders to improve the consistency. In order not to disqualify all stakeholders, which would have been the case if a CR of 0.1 had been used as a limit for acceptable inconsistency, a CR of 0.3 was used as a limit. This limit meant that $20 \%$ of the timber producers, $25 \%$ of the environmentalists, and $57 \%$ of the recreationists were removed from the calculations of the final ranking.

A ranking of the alternatives was determined for each social group by computing the arithmetic mean of the global priorities for alternatives of each respondent belonging to the social group. The weights attached to the four social groups by the individual steering group members were aggregated by the arithmetic mean. These weights were then used to aggregate the global priorities for alternatives for the social groups by computing a weighted arithmetic mean. This resulted in the aggregated or overall ranking of the alternatives shown in Table 3. 
Table 3. Weights for the social groups, global priorities for alternatives of each social group, and the aggregated global priorities obtained by weighed arithmetic mean (individuals with judgments where CR $>0.3$ are not included)

\begin{tabular}{llllll}
\hline & $\begin{array}{l}\text { Timber } \\
\text { producers }\end{array}$ & Environmentalists & Recreationists & $\begin{array}{l}\text { Reindeer } \\
\text { herders }\end{array}$ & $\begin{array}{l}\text { Aggregated global } \\
\text { priorities }\end{array}$ \\
\hline $\begin{array}{l}\text { Group } \\
\text { weight }\end{array}$ & 0.504 & 0.170 & 0.242 & 0.085 & \\
Plan A & 0.211 & 0.486 & 0.386 & 0.361 & 0.313 \\
Plan B & 0.305 & 0.071 & 0.132 & 0.074 & 0.204 \\
Plan C & 0.484 & 0.443 & 0.481 & 0.566 & 0.484 \\
\hline
\end{tabular}

The results were presented to and discussed by the steering group at a meeting. In general, the results were accepted and approved by the steering group; the discussions tended to be about how the plan should be implemented and concerned issues at the stand level rather than the plan for the forest as a whole. The municipality will integrate the plan into existing forest management plans. The forest companies expressed a will to use the plan as a tool in their planning processes, but they have not formally undertaken to pursue the plan. The steering group also agreed to test a routine for consultations in the planning of silvicultural treatments. All treatments planned within zone 1, 2 and 3 (Fig. 4) will be reported by the forest managers to the municipality ecologist, who will in turn announce the plans to the reference network via email and to the public via the municipality homepage. Comments and views will then be compiled by the municipality ecologist, and discussed with the forest manager. If the planned sivlicultural treatment seems controversial, a meeting with concerned parties, if possible out in the forest, will be organized. 


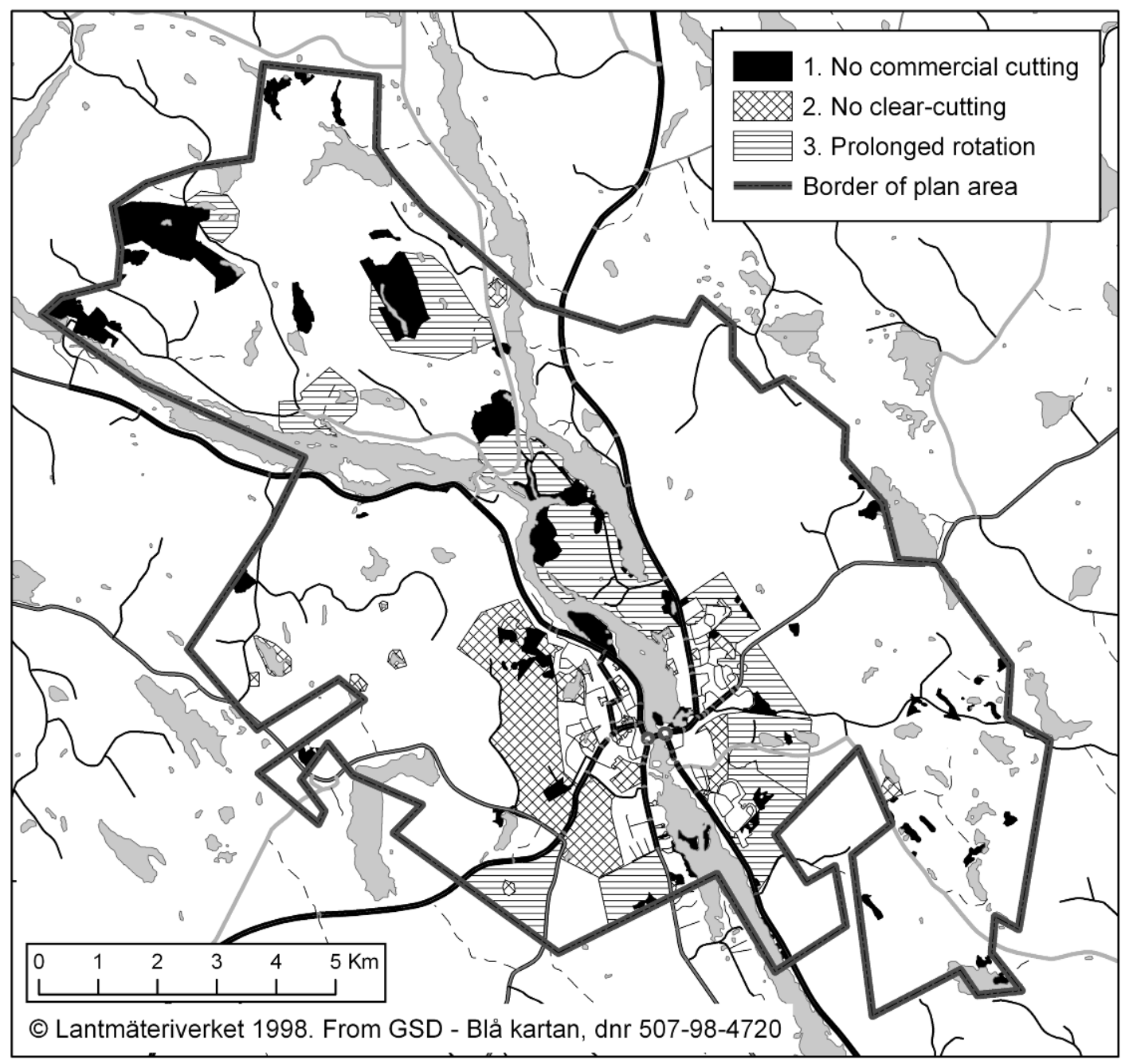

Figure 4. Zonal map for the case study. In the zonal map, the urban forest is divided into four different forest management classes, which are used as inputs in the creation of the three forest plan alternatives. The three zones with adapted management are shown in the map: 1) zone with no commercial cutting, 2) zone with no clear-cutting, and 3) zone with prolonged rotation time. Standard forest management is practiced in the rest of the plan area (zone 4).

The results of the process - with focus on the present forest condition, the preferences of the different social groups, the forest management zones and the zonal map - were presented to the stakeholder representatives at a meeting. The consultation routine was also presented, discussed and the testing of it generally approved. In addition, the project and its outcomes were presented to the public at a forest day in Lycksele. 


\section{Assessment of the process}

In this section, the strengths and weaknesses of the participatory MCDA process of the case study will be assessed, and some specific issues raised in this assessment will be discussed in the next section. The assessment is based on the authors' observations of the process, the outcomes in terms of numerical and other results, and the authors' interpretations of observations and outcomes. Thus, this assessment is not a proper evaluation, but rather an attempt to illustrate different aspects of the case study.

We assess the case study against the five social goals for the analysis of public participation in natural resource management formulated by Beierle and Cayford (2002):

1. Incorporating public values into decisions

2. Improving the substantive quality of decisions

3. Building trust in institutions

4. Resolving conflict among competing interests

5. Educating and informing the public

This set of goals includes both the outcome-focused view and the process-focused view: the second goal is related to the material outcome of the process, while goals $1,3,4$, and 5 are more connected to the benefits of the process in itself. The fulfillment of the goals is assessed for each step in the process and summarized for the process as a whole as a statement on a verbal scale of "Low", "Medium”, and "High” as described by Beierle and Cayford (2002). Table 4 shows a summary of the assessment; issues that are commented on in this section are highlighted in bold type. It should be noted that the outcome of the participatory process is assessed against the situation prior to the process, not against scenarios of alternative processes using other methods. 
Table 4. Assessment of how the steps of the participatory MCDA process contribute to fulfilling the social goals defined by Beierle and Cayford (2002). The assessment scale has three degrees: + corresponds to "Low”, ++ corresponds to "Medium", +++ corresponds to "High". Specific results that are mentioned further in section 4 are highlighted in bold type

\begin{tabular}{|c|c|c|c|c|c|c|}
\hline & $\begin{array}{l}\text { Stakeholder } \\
\text { analysis }\end{array}$ & $\begin{array}{c}\text { Structuring of } \\
\text { the decision } \\
\text { problem }\end{array}$ & $\begin{array}{l}\text { Generation } \\
\text { of } \\
\text { alternatives }\end{array}$ & $\begin{array}{c}\text { Elicitation } \\
\text { of } \\
\text { preferences }\end{array}$ & $\begin{array}{l}\text { Ranking of } \\
\text { alternatives }\end{array}$ & Total \\
\hline $\begin{array}{l}\text { 1. Incorporating } \\
\text { public values into } \\
\text { decisions }\end{array}$ & ++ & + & + & & +++ & \\
\hline $\begin{array}{l}\text { 2. Improving the } \\
\text { substantive quality } \\
\text { of decisions }\end{array}$ & +++ & +++ & +++ & $++t$ & +++ & \\
\hline $\begin{array}{l}\text { 3. Building trust in } \\
\text { institutions }\end{array}$ & ++ & +++ & +++ & ++ & ++ & \\
\hline $\begin{array}{l}\text { 4. Resolving conflict } \\
\text { among competing } \\
\text { interests }\end{array}$ & ++ & + & ++ & ++ & ++ & $+t$ \\
\hline $\begin{array}{l}\text { 5. Educating and } \\
\text { informing the public }\end{array}$ & + & +4 & + & + & + & + \\
\hline
\end{tabular}

\subsection{Incorporating public values into decisions}

By combining participatory planning with MCDA, information from stakeholders was incorporated in the structuring of the decision problem, into the alternatives, and as preferences in the decision-making.

A stakeholder analysis was performed to ensure that all relevant parties were included. The stakeholder analysis was based on input from the steering group. The public values were articulated by representative stakeholders and not by the public directly. However, the representatives reflected the public in terms of their socioeconomic situations and occupations. One may note, however, that the distribution between men and women was skewed as a majority of the representatives was men.

The stakeholders participated in the structuring of the decision problem by expressing their own criteria. A certain category of place-specific criteria seemed to be very common in this case study, especially for the recreationist group. These refer to particular areas or stands, e.g., "Do not clear-cut this stand or this area". These criteria involve the location of the stand as well as the present character of the forest. The maps used in the interviews gave the stakeholders opportunity to express also place-specific criteria, which otherwise might have been neglected. 
The high level of inconsistency in stakeholder judgments in this case is problematic. A relatively large number of highly inconsistent judgments were omitted from analysis, which means that the weights for criteria and alternatives and the final ranking of alternatives do not include the values of all stakeholders that were found relevant in the stakeholder analysis. On the other hand, highly inconsistent judgments may not reflect the stakeholders’ preferences very well, and to include them would also affect the outcome.

Three alternatives were presented to the stakeholders. That plan C was ranked highly overall by all social groups may indicate that this plan covered the stakeholders' values very well. On the other hand, the high rank of plan C may indicate that the alternatives did not cover the criteria space of stakeholders properly, and that plan C was only the "least worst alternative”.

How the values of stakeholders were incorporated was also influenced by the aggregating of individual preferences into a common preference. The steering group made judgments on the importance of each of the four social groups, so the groups were not weighted equally. Thus, the timber producers had the highest influence, followed by recreationists, environmentalists, and reindeer herders.

On the whole, the fulfillment of this goal is judged to be high, because the MCDA provided good opportunities to incorporate public values throughout the process.

\subsection{Improving the substantive quality of decision}

In the case study, new information was produced about criteria and areas important for the stakeholders, and management plans were generated based on that information. MCDA also generated knowledge about stakeholders' preferences and trade-offs between different social groups' criteria. Inclusion of stakeholders in the identification of criteria ought to have helped to structure the problem accurately. Thus, we assume that the total social benefit have increased from the process. The outcome of the process in this case study may have increased the stakeholders' satisfaction compared with the status quo; there are no signs that satisfaction had decreased.

That only three alternatives were generated and evaluated by stakeholders is most likely a limitation for the possibility of improving the substantive quality of the decision. If more alternatives had been evaluated, or alternatives had been developed and refined in an iterative process, a plan of higher substantive quality might have been identified.

As for the cost-effectiveness of the process, it can be said that the cost in time and money for the representatives and the public was very low. The interviews with representatives 
lasted between 30 and 90 minutes, the feedback meeting held with the steering group and the representatives took 2 hours, and the inquiry form for preferences took about 1 hour to fill out. As for the public, the enquiry form provided during the open meeting for the public took about 5 minutes to fill in. The time required for the process by the steering group was longer but still moderate. The forest owners of the steering group were interviewed for between 30 and 90 minutes, during which time they provided forest data from their databases to the authors. The steering group also attended the 2-hour feedback meeting and filled out the preference inquiry form. In addition, there have been three meetings with the steering group lasting about 3 hours each, and the steering group has also been required to provide feedback on various issues, such as the zonal map. The highest cost must be attributed to the municipality ecologist and the authors for the time spent planning and realizing the process; no estimation is attempted here, but it can be said that neither the municipality ecologist nor the authors worked full time with the project. Because the process is presumed to have had some positive effect on the outcome for the public and to have provided a plan to prevent conflicts, thus facilitating the implementation process for the forest owners, the process is judged to have been cost effective.

The score on this goal is set as high because the process has most likely improved the quality of the decisions from a societal perspective in a cost-efficient way.

\subsection{Building trust in institutions}

The use of MCDA has helped to make the decision-making process transparent, because the basis for the final choice of plan can be traced back through the MCDA process. This may have increased the trust in forest owners by other social groups. The participatory approach in itself may have increased the trust in the forest owners, because they initiated the process without any obligation to do so. However, overall, more and repeated interaction would have been needed to build trust among all stakeholders in the process (Ansell and Gash, 2008).

In the steering group that met repeatedly, a certain level of trust was built. From initially being very much the representatives of their organizations, some pursuing a wait-and-see policy, the atmosphere seemed to have changed in meetings and a shared understanding developed towards the end of the process. Discussions about the implications and fairness of the plan for the different forest owners were constructive and there was a general will to find solutions that worked, e.g., the consultation model. 
In all, the score on this goal is medium because the trust has most likely not changed generally among stakeholders; rather, trust was built among the members of the steering group, if not among the stakeholders in general.

\subsection{Resolving conflict among competing interests}

In the beginning of the process, the potential for open conflict among stakeholders was judged to be low. During the process, the interaction among stakeholders with potentially competing interests was very low; this means there was no confrontation, but also that the opportunity for resolving latent conflicts at this stage was lost. More meetings and discussions between stakeholders could have promoted an understanding for other perspectives. On the other hand, and perhaps due to the perceived low degree of conflict, public meetings were not well attended. However, in the steering group that met repeatedly, the capacity to discuss issues of conflict may have increased.

The use of MCDA provided the forest owners with information about conflicting interests. Criteria weights from the different social groups, the zonal map and the plan alternatives were all used to discuss conflicting interests. However, because there were only three alternatives, some conflicts may not have been revealed. That plan $\mathrm{C}$ was ranked highly by all stakeholders may be an indication of this. Furthermore, conflicting interests were probably hidden in the construction of one single zonal map; several alternative zonal maps could have been produced and preferences for these would most likely have differed between stakeholders.

The basis for setting the score of this goal to medium is the potential for preventing future conflicts; the awareness among the forest owners of likely causes for conflicts have been increased through new knowledge about stakeholder objectives and preferences gained in the process.

\subsection{Educating and informing the public}

During the process, the information flow from stakeholders to decision-makers (the steering group) about criteria and preferences has been the principal form of interaction. In this study, we used individual interviews for identifying criteria. Direct, two-way interaction among all stakeholders was thus limited to one common meeting during the process, and this meeting was poorly attended.

The participation in the present case study was mainly conducted through representatives from different organizations, not through direct public participation where individuals state 
their own personal interests. Thus, the educating and informing effect is probably smaller than it could have been. On the other hand, with this mode of working, the representatives had in general a certain degree of basic knowledge beforehand and were better able to participate in this complicated issue, something which was probably necessary when more advanced MCDA technique like AHP was used with only a little support.

In all, the intensity of the process and the interaction among stakeholders was so small that the fulfillment of this goal is low.

\section{Discussion}

The assessment of the process indicates that the integration of MCDA and participatory planning is a promising approach for handling complex forest planning situations with multiple stakeholders and conflicting criteria. One strength is that the MCDA process incorporated stakeholder values in a structured way that ensured a certain degree of transparency of the decision-making process. Furthermore, the MCDA process potentially increased the substantive quality of decisions by balancing interests against each other, thereby producing solutions of higher overall stakeholder satisfaction. The score on goals such as conflict resolution and education could have benefited from a different management that would have intensified the interaction among stakeholders, for instance with more meetings with more direct public participation during a shorter period. On the other hand, the public meeting met with limited response, indicating that interaction that is more intensive may be difficult to achieve when, as was the case here, the situation is rather neutral to start with.

Apart from the general properties of the process the assessment points to some more specific issues. A weakness is that an extensive stakeholder analysis can be difficult to conduct if there is little initial knowledge of the situation and few known stakeholders. In this case, the stakeholder analysis was greatly facilitated by the existing networks with representatives from different organizations that could be used. However, there is always the question of whether the representative stakeholders really represented public opinion and not only their organization's or personal interests (Beierle and Cayford, 2002; Buchy and Hoverman, 2000). An additional problem with using existing networks, such as in this case study, is that the same individuals may always end up representing the public interest, as a kind of professional public representative. On the other hand, if individuals have been 
involved repeatedly as representatives, they are likely to be committed to the question at hand and to have accumulated knowledge about the situation and possibly about the MCDA techniques.

We found it important to give stakeholders the opportunity to express their own objectives. The reasons were the same as for conducting a proper stakeholder analysis; firstly, to accurately structure the problem and thereby improve the substantive quality of the decision from a societal perspective; secondly, to make the process transparent and legitimate to the stakeholders, and thus facilitate the implementation. To let only the decision-maker or experts formulate criteria would have undermined the gist of the participatory process, because we would not be sure that stakeholders' criteria had been accurately represented. In this study we used individual interviews; the main reasons were the pure logistical problem of gathering all stakeholders at the same time and ensuring that all stakeholders were heard. Other useful methods might have been focus groups or workshops using cognitive mapping (Eden, 1988) or systems thinking (Checkland, 1981). A collective identification of criteria would give the stakeholders opportunities for learning about each other's values and develop a shared understanding of the problem, but the process should be carefully facilitated to avoid suppression of some values in the search for consensus (Peterson et al., 2005) or groupthink, which may occur when the unity of the group obstructs critical and independent thinking (Janis, 1972).

Place-specific criteria seemed to be important to stakeholders in this case study. This corresponds the observations of Kangas et al. (2008) that mapping of social values is more in line with how people perceive their environment than with the more abstract and generalized criteria commonly defined in MCDA. It would not have been possible to include these placespecific criteria in an ordinary objective hierarchy, because their full expression would lead to an impossibly large tree. We chose to solve the problem with this type of criteria by collapsing the demarcations of important areas by different stakeholders into one "average" zonal map that was subsequently used as the basis for the different plan alternatives. Thus, the stakeholders could not explicitly state their preferences for different sets of areas with different management regimes.

Because we chose to use the AHP and requested the stakeholders to evaluate the plans and give their preferences in form of "pairwise" comparisons, the number of alternatives had to be restricted. According to Saaty (1990), the maximum number of objects that a person can compare, and still be consistent in judgment, is seven. In this case study, where stakeholders were to make judgments on such complex objects as forest plans, the maximum number of 
alternatives they would be able to compare could be expected to be even less than seven. We chose to present only three alternatives because we deemed that more than three alternatives would demand too large a number of comparisons to be made by the stakeholders. However, the need to reduce the number of comparisons has to be balanced against the risk of indirectly guiding the process towards a certain solution by reducing the range of alternatives too much. Thus, this step is by its very nature a multiple objective problem for the analyst.

In a participatory process involving a large number of nonprofessional stakeholders, personal meetings and an iterative method can be too demanding and time consuming for the analyst. In addition, there is also the problem of unwillingness among stakeholders to engage in a participatory process (see, e.g., Cheng and Mattor, 2006); thus, the process should be efficient with respect to the time and effort required from stakeholders. This indicates a need for even simpler and more intuitive techniques than AHP (Kangas and Kangas, 2005). We chose AHP as the technique to elicit preferences and rank the alternatives, because AHP is one of the MCDA techniques most frequently applied in case studies in the field of forest/natural resource management (Mendoza and Martins, 2006). The technique is described as being rather straightforward; the pairwise comparison procedure is assumed to facilitate the judgment process for the stakeholders. However, the rather high CR required here indicates that this technique will probably work best if the stakeholders can state their preferences with the help of the analyst in an individual session. The number of comparisons probably contributes to the high inconsistency, as does the complexity of the forest plan alternatives, where many criteria were presented not only as one resulting number but also as diagrams showing the results for each period.

There is also the aggregation of preferences to consider. The procedure of aggregating individual rankings used in this case study makes the weights for the different social groups momentous to the outcome of the final overall ranking. Thus, the weights should not be set by the analyst but be included in the process. Because the steering group had expressed the wish that the forest owners should retain the ultimate power over the decision making in the process, the steering group was assigned the task to make judgments on the importance of the four social groups. To get a higher level of participation in the process, one option would have been to let all stakeholders make judgments on the importance of the social groups.

All this said, it should be acknowledged that the assessment is not a proper evaluation; no data was collected specially for this purpose, and the assessment is based on results from the case study and observations from the process by the authors. Still, according to Beierle (1998), the framework used can "be objective in the sense of not explicitly taking the 
perspective of any one party to a particular decision, and measure - to the extent feasible tangible outcomes from participation”. Other criteria than the five social goals of Beierle and Cayford (2002) could also be employed. Evaluation or success criteria for participatory processes have been developed and proposed in many different studies (e.g., Beierle and Cayford, 2002; Blackstock et al., 2007; Chess and Purcell, 1999; Germain et al., 2001; Hamersley Chambers and Beckley, 2003; Webler et al., 2001). These evaluation criteria are based on different perspectives, theories and situations, and there is no best general set of criteria for evaluating the success of a participatory process. Our main reason for choosing the framework of Beierle and Cayford (2002) for our assessment is that it has been used for evaluation of existing case studies (Beierle and Cayford, 2002). Thus, there are practical guidelines for assessing the fulfillment of the goals. Another advantage is that the framework, as mentioned earlier, includes both the outcome-focused view and the process-focused view.

\section{Conclusions}

The study shows that the combination of participatory planning and the MCDA process is a viable option. Indications to that effect are that the current application of the methodology resulted in a plan that was integrated into the existing forest plan of the municipality. It also gave rise to a new consultation procedure for forest management actions in areas identified as sensitive. We do not claim that the process as it was implemented here is optimal. Still, the exercise here can hopefully contribute to the development of protocols for common usage of MCDA-based participatory planning. A lot of development work still remains. We have identified four key issues related to the MCDA methodology that need to be explored further:

1. First, there is the case of place-specific criteria. We believe that this kind of criteria is frequently expressed by stakeholders in participatory forest planning in general.

Furthermore, this kind of criteria must be handled in some way in order to make use of information and preferences provided by stakeholders.

2. Procedures for developing alternatives should be explored. Often a noniterative work mode where discrete alternatives are presented to the stakeholders is convenient, saves time, and is sometimes the only option. Because the possible outcome of the decision-making situation is restricted to the set of alternatives, it is important that the alternatives are Pareto efficient and realistic (i.e., implementable), that there are not 
too many, and that they simultaneously span the criteria space in a way that reflects stakeholders’ interests.

3. The aggregation of individual preferences should be explored further, because this procedure controls the degree of different stakeholders' influences on the outcome. The aggregation procedure ought to be not only methodologically sound but also fair from a stakeholder point of view.

4. Finally, to enable decision-makers to make practical use of the powerful tool that the combination of participatory planning and MCDA provides, studies have to be directed toward the application of this approach in real case studies. Moreover, there is a need for studies that describe and evaluate the whole process. As the assessment in this study shows, an increased focus on the participatory aspect may improve the fulfillment of the social goals and bring out this tool's full potential. 


\section{Appendices}

\section{Appendix A}

\section{Table A.1}

List of stakeholders chosen to participate in the process, resulting from the stakeholder analysis.

\begin{tabular}{|c|c|c|c|}
\hline $\begin{array}{l}\text { Timber } \\
\text { producers }\end{array}$ & Environmentalists & Recreationists & $\begin{array}{l}\text { Reindeer } \\
\text { herders }\end{array}$ \\
\hline $\begin{array}{l}\text { Church of } \\
\text { Sweden }\end{array}$ & $\begin{array}{l}\text { County Board of } \\
\text { Västerbotten }\end{array}$ & Ansia Camping & $\begin{array}{l}\text { Ubmeje } \\
\text { tjeälddie } \\
\text { (Umbyn's } \\
\text { reindeer } \\
\text { herding } \\
\text { district) }\end{array}$ \\
\hline Holmen & $\begin{array}{l}\text { Lappmarkens } \\
\text { skogsgrupp }\end{array}$ & Friluftsfrämjandet & \\
\hline $\begin{array}{l}\text { Lycksele } \\
\text { municipality }\end{array}$ & Ornithologist & $\begin{array}{l}\text { Fritidsenheten/Folkhälsorådet, } \\
\text { Lycksele municipality }\end{array}$ & \\
\hline $\begin{array}{l}\text { Private forest } \\
\text { owners }\end{array}$ & $\begin{array}{l}\text { Swedish Forest } \\
\text { Agency }\end{array}$ & Gammplatsen/Hembygdsgillet & \\
\hline $\begin{array}{l}\text { Svenska } \\
\text { Cellulosa AB }\end{array}$ & $\begin{array}{l}\text { Swedish Society for } \\
\text { Nature Conservation }\end{array}$ & Guidepoolen & \\
\hline Sveaskog & & $\begin{array}{l}\text { Handikappförbundens } \\
\text { samarbetsorgan } \\
\text { Korpen } \\
\text { Lappmarksryttarna } \\
\text { Lycksele } \\
\text { fiskevårdsområdesförening } \\
\text { Lycksele IF } \\
\text { Närnaturguide } \\
\text { Primary schools } \\
\text { Sameföreningen } \\
\text { Snowled, Skoterföreningarna i } \\
\text { Lycksele } \\
\text { Study Promotion Association } \\
\text { Swedish Association for Hunting } \\
\text { and Wildlife Management } \\
\text { Swedish Tourist Association } \\
\text { Tannbergsskolan (preparatory high } \\
\text { school): Skidgymnasiet and } \\
\text { Naturbruksprogrammet }\end{array}$ & \\
\hline
\end{tabular}




\section{Appendix B}

Basic questions used in the interviews with stakeholders.

Questions about values and criteria:

- How do you and your organization use the urban forest?

- What is important to you in the urban forest?

Questions about the map:

- What areas do you use?

- What areas are important to you?

- How do you use each area?

- What would you like the forest to look like in these areas? What kind of silviculture could create the values you want?

- Can you give a priority to the different areas?

1. This area is very important.

2. This area is important.

3. This area is somewhat important.

Additional questions:

- What are your expectations from this project?

- What do you think about other activities and stakeholders in the urban forest?

- How many people use the forest for the same activity as you?

- How do your activities affect the forest? Are they good or bad for you or other stakeholders?

- How do other stakeholders' activities affect the forest? Are they good or bad for you or other stakeholders? 


\section{Appendix C}

Table C.1

Consistency ratios (CRs) obtained for alternative and criteria matrices of the timber producers

\begin{tabular}{|c|c|c|c|c|c|c|c|}
\hline & \multicolumn{5}{|c|}{ CR for alternative matrices } & \multicolumn{2}{|c|}{$\begin{array}{l}\text { CR for criteria } \\
\text { matrices }\end{array}$} \\
\hline & $\begin{array}{l}\text { Net } \\
\text { present } \\
\text { value }\end{array}$ & $\begin{array}{l}\text { Harvest } \\
\text { flow }\end{array}$ & $\begin{array}{l}\text { Fertilized } \\
\text { area }\end{array}$ & $\begin{array}{l}\text { Thinning } \\
\text { area }\end{array}$ & $\begin{array}{l}\text { Area of } \\
\text { lodgepole } \\
\text { pine }\end{array}$ & $\begin{array}{l}\text { Higher } \\
\text { level }\end{array}$ & $\begin{array}{l}\text { Lower } \\
\text { level }\end{array}$ \\
\hline $\begin{array}{l}\text { Timber } \\
\text { producer } 1\end{array}$ & 0.282 & 0.158 & 0.117 & 0.117 & 0.117 & 0 & 0 \\
\hline $\begin{array}{l}\text { Timber } \\
\text { producer } 2\end{array}$ & 0.201 & 0.011 & 0 & 0.033 & 0 & 0.117 & 0.117 \\
\hline $\begin{array}{l}\text { Timber } \\
\text { producer 3* }\end{array}$ & 0.484 & 0 & 0 & 0 & 0 & 0.117 & 0.011 \\
\hline $\begin{array}{l}\text { Timber } \\
\text { producer } 4\end{array}$ & 0.069 & 0.158 & 0.033 & 0.254 & 0.006 & 0.033 & 0.117 \\
\hline $\begin{array}{l}\text { Timber } \\
\text { producer } 5\end{array}$ & 0.158 & 0.254 & 0.056 & 0.283 & 0.117 & 0 & 0.254 \\
\hline
\end{tabular}

Note: The stakeholder marked with * was omitted from the final aggregation because of high inconsistency (CR > 0.3).

\section{Table C.2}

Consistency ratios (CRs) obtained for alternative and criteria matrices of the environmentalists

\begin{tabular}{llllll}
\hline Stakeholder & \multicolumn{2}{l}{ CR for alternative matrices } & & $\begin{array}{l}\text { CR for } \\
\text { criteria } \\
\text { matrix }\end{array}$ \\
& \multicolumn{2}{l}{ Old forest } \\
& area & $\begin{array}{l}\text { Clear-cut } \\
\text { size }\end{array}$ & $\begin{array}{l}\text { Proportion of } \\
\text { birch }\end{array}$ & $\begin{array}{l}\text { Total clear- } \\
\text { cut area }\end{array}$ & \\
\hline Environmentalist 1 & 0 & 0 & 0 & 0 & 0.045 \\
Environmentalist 2* & 0.484 & 0.449 & 0.254 & 0.117 & 0.047 \\
Environmentalist 3 & 0.254 & 0.117 & 0.254 & 0.254 & 0.253 \\
Environmentalist 4 & 0.117 & 0.117 & 0.033 & 0.011 & 0.057 \\
\hline
\end{tabular}

Note: The stakeholder marked with * was omitted from the final aggregation because of high inconsistency (CR > 0.3). 


\section{Table C.3}

Consistency ratios (CRs) obtained for alternative and criteria matrices of the recreationists

\begin{tabular}{|c|c|c|c|c|c|c|}
\hline \multirow[t]{2}{*}{ Stakeholder } & \multicolumn{5}{|c|}{ CR for alternative matrices } & \multirow{2}{*}{$\begin{array}{l}\text { CR for } \\
\text { criteria } \\
\text { matrix }\end{array}$} \\
\hline & $\begin{array}{l}\text { Old } \\
\text { forest } \\
\text { area } \\
\end{array}$ & $\begin{array}{l}\text { Clear- } \\
\text { cut size }\end{array}$ & $\begin{array}{l}\text { Proportion } \\
\text { of birch } \\
\text { and spruce }\end{array}$ & $\begin{array}{l}\text { Total } \\
\text { clear-cut } \\
\text { area }\end{array}$ & $\begin{array}{l}\text { Area planted } \\
\text { with lodgepole } \\
\text { pine }\end{array}$ & \\
\hline Recreationist 1 & 0.117 & 0.254 & 0 & 0.147 & 0 & 0.332 \\
\hline Recreationist 2 & 0.033 & 0.254 & 0.033 & 0.117 & 0.117 & 0.126 \\
\hline Recreationist 3* & 0.158 & 0.158 & 0.524 & 0.158 & 0.254 & 0.581 \\
\hline Recreationist 4* & 0.011 & 0.254 & 0.254 & 0.180 & 0 & 0.420 \\
\hline Recreationist 5* & 0.254 & 0.158 & 0.117 & 0.201 & 0.178 & 0.697 \\
\hline Recreationist 6 & 0.254 & 0.254 & 0.254 & 0.254 & 0.117 & 0.338 \\
\hline Recreationist 7* & 0.254 & 1.359 & 0.056 & 0.056 & 0.033 & 0.230 \\
\hline
\end{tabular}

Note: Stakeholders marked with * were omitted from the final aggregation because of high inconsistency (CR > 0.3).

Table C.4

Consistency ratios (CRs) obtained for alternative and criteria matrices of the reindeer herder

\begin{tabular}{|c|c|c|c|c|c|c|c|}
\hline \multirow[t]{2}{*}{ Stakeholder } & \multicolumn{6}{|c|}{ CR for alternative matrices } & \multirow{2}{*}{$\begin{array}{l}\text { CR for } \\
\text { criteria } \\
\text { matrix }\end{array}$} \\
\hline & $\begin{array}{l}\text { Thinning } \\
\text { area }\end{array}$ & $\begin{array}{l}\text { Old } \\
\text { forest } \\
\text { area }\end{array}$ & $\begin{array}{l}\text { Clear- } \\
\text { cut } \\
\text { size }\end{array}$ & $\begin{array}{l}\text { Total } \\
\text { clear- } \\
\text { cut } \\
\text { area }\end{array}$ & $\begin{array}{l}\text { Area planted } \\
\text { with } \\
\text { lodgepole } \\
\text { pine }\end{array}$ & $\begin{array}{l}\text { Fertilized } \\
\text { area }\end{array}$ & \\
\hline $\begin{array}{l}\text { Reindeer } \\
\text { herder } 1\end{array}$ & 0.283 & 0.254 & 0.117 & 0.254 & 0.117 & 0.056 & 0.314 \\
\hline
\end{tabular}




\section{Acknowledgements}

We thank the forest owners and the other participants in the planning process in Lycksele for the time and effort they have put into this project. We are especially grateful to municipality ecologist Ingela Forsberg for her dedicated support throughout the process. The project was financially supported by the Lycksele municipality, the Church of Sweden, Holmen, Sveaskog, SCA and the Swedish Forest Society (Skogssällskapet). Comments and suggestions from two anonymous reviewers have improved the clarity and accuracy of the paper.

\section{References}

Ananda, J., Herath, G., 2003a. Incorporating stakeholder values into regional forest planning: A value function approach. Ecol. Econ. 45, 75-90.

Ananda, J., Herath, G., 2003b. The use of Analytic Hierarchy Process to incorporate stakeholder preferences into regional forest planning. For. Policy Econ. 5, 13-26. Ansell, C., Gash, A., 2008. Collaborative governance in theory and practice. J. Publ. Adm. Res. Theor. 18, 543-571.

Arnstein, S.R., 1969. A ladder of citizen participation. J. Am. Plan. Assoc. 35, 216-224.

Banville, C., Landry, M., Martel, J.M., Boulaire, C., 1998. A stakeholder approach to MCDA. Syst. Res. Behav. Sci. 15, 15-32.

Beierle, T.C., 1998. Public participation in environmental decisions: an evaluation framework using social goals. Resources for the Future. Discussion Paper 99-06. Washington D.C.

Beierle, T.C., Cayford, J., 2002. Democracy in practice: Public participation in environmental decisions. Resources for the Future Press, Washington, D.C.

Belton, V., Pictet, J., 1997. A framework for group decision using a MCDA model: Sharing, aggregating or comparing individual information? Rev. Syst. Décis. 6, 283-303.

Belton, V., Stewart, T.J., 2002. Multiple Criteria Decision Analysis-an integrated approach. Kluwer Academic Publishers, Dordrecht, The Netherlands.

Berkes, F., 1994. Co-management: Bridging the two solitudes. North. Perspect. 22, 18-20.

Blackstock, K.L., Kelly, G.J., Horsey, B.L., 2007. Developing and applying a framework to evaluate participatory research for sustainability. Ecol. Econ. 60, 726-742. 
Buchy, M., Hoverman, S., 2000. Understanding public participation in forest planning: A review. For. Policy Econ. 1, 15-25.

Campbell, T., 1996. Co-management of aboriginal resources. Inf. North 22, 1-6.

Campo, P.C., Mendoza, G.A., Guizol, P., Villanueva, T.R., Bousquet, F., 2009. Exploring management strategies for community-based forests using multi-agent systems: A case study in Palawan, Philippines. J. Environ. Manag. 90, 3607-3615.

Castelletti, A., Soncini-Sessa, R., 2006. A procedural approach to strengthening integration and participation in water resource planning, Environ. Modell. Softw. 21, 1455-1470.

Checkland, P., 1981. Systems Thinking, Systems Practice. John Wiley and Sons, New York.

Cheng, A., Mattor, K., 2006. Why won’t they come? Stakeholder perspectives on collaborative national forest planning by participation level. Environ. Manag. 38, 545561.

Chess, C., Purcell, K., 1999. Public participation and the environment: Do we know what works? Environ. Sci. Technol. 33, 2685-2692.

Diaz-Balteiro, L., Romero, C., 2008. Making forestry decisions with multiple criteria: A review and an assessment. For. Ecol. Manag. 255, 3222-3241.

Eden, C., 1988. Cognitive mapping. Eur. J. Oper. Res. 36, 1-13.

Eriksson, L.O., 1983. Timber class formation by cluster analysis. Swedish University of Agricultural Sciences, Department of Forest Technology. Report No. 157. Garpenberg, Sweden.

Germain, R.H., Floyd, D.W., Stehman, S.V., 2001. Public perceptions of the USDA Forest Service public participation process. For. Policy Econ. 3, 113-124.

Grimble, R., Wellard, K., 1997. Stakeholder methodologies in natural resource management: a review of principles, contexts, experiences and opportunities. Agr. Syst. 55, 173-193.

Hamersley Chambers, F., Beckley, T., 2003. Public involvement in sustainable boreal forest management, in: Burton, P.J., Messier, C., Smith, D.W., Adamowicz, W.L. (Eds.), Towards sustainable management of the boreal forest. NRC Research Press, Ottawa, Canada, pp. 113-154.

Hiltunen, V., Kurttila, M., Leskinen, P., Pasanen, K., Pykäläinen, J., 2009. Mesta: An internet-based decision-support application for participatory strategic-level natural resources planning. For. Policy Econ. 11, 1-9.

Hoen, H.F., Eid, T., 1990. En modell for analyse av behandlingsstrategier for en skog ved bestandssimulering og lineær programmering. [A model for analysis of forest 
management strategies in stand simulation and linear programming. In Norwegian ] Rapport / Norsk institutt for skogforskning - NISK, 90:9. Ås, Norway.

IAP2, 2007. IAP2 Spectrum of Public Participation.

http://www.iap2.org/associations/4748/files/IAP2\%20Spectrum_vertical.pdf. Accessed 4 January, 2010.

Janis, I.L., 1972. Victims of groupthink. Houghton Mifflin Company, Boston.

Johnson, K.N., Scheurman, H.L., 1977. Techniques for prescribing optimal timber harvest and investment under different objectives_-discussion and synthesis. For. Sci., Monograph 18 (Supplement to Number 1, 1 March 1977).

Kangas, A., Kangas, J., Pykäläinen, J., 2001. Outranking methods as tools in strategic natural resources planning. Silva Fenn. 35, 215-227.

Kangas, A., Haapakoski, R., Tyrväinen, L., 2008. Integrating place-specific social values into forest planning - Case of UPM-Kymmene forests in Hyrynsalmi, Finland. Silva Fenn. 42, 773-790.

Kangas, A., Saarinen, N., Saarikoski, H., Leskinen, L.A., Hujala, T., Tikkanen, J., 2010. Stakeholder perspectives about proper participation for Regional Forest Programmes in Finland. For. Policy Econ. 12, 213-222.

Kangas, J., Kangas, A., 2005. Multiple criteria decision support in forest management- the approach, methods applied, and experiences gained. For. Ecol. Manag. 207, 133-143.

Kangas, J., Store, R., 2003. Internet and teledemocracy in participatory planning of natural resources management. Landsc. Urban Plan. 62, 89-101.

Keeney, R.L., 1992. Value-Focused Thinking-A Path to Creative Decisionmaking. Harvard University Press, Cambridge.

Lahdelma, R., Salminen, P., Hokkanen, J., 2000. Using multicriteria methods in environmental planning and management. Environ. Manag. 26, 595-605.

Laukkanen, S., Palander, T., Kangas, J., 2004. Applying voting theory in participatory decision support for sustainable timber harvesting. Can. J. For. Res. 34, 1511-1524.

Malczewski, J., 1999. GIS and Multicriteria Decision Analysis. John Wiley and Sons, New York.

Maness, T., Farrell, R., 2004. A multi-objective scenario evaluation model for sustainable forest management using criteria and indicators. Can. J. For. Res. 34, 2004-2017.

Mendoza, G.A., Martins, H., 2006. Multi-criteria decision analysis in natural resource management: A critical review of methods and new modelling paradigms. For. Ecol. Manag. 230, 1-22. 
Mendoza, G.A., Prabhu, R., 2005. Combining participatory modeling and multi-criteria analysis for community-based forest management. For. Ecol. Manag. 207, 145-156.

Munda, G., 2004. Social multi-criteria evaluation: Methodological foundations and operational consequences. Eur. J. Oper. Res. 158, 662-677.

Peterson, M.N., Peterson, M.J., Peterson, T.R., 2005. Conservation and the myth of consensus. Conserv. Biol. 19, 762-767.

Phillips, R.A., 1997. Stakeholder theory and a principle of fairness. Bus. Ethics Q. 7, 51-66.

Pykäläinen, J., Kangas, J., Loikkanen, T., 1999. Interactive decision analysis in participatory strategic forest planning: Experiences from state owned boreal forests. J. For. Econ. 5, 341-364.

Rauschmayer, F., Wittmer, H., 2006. Evaluating deliberative and analytical methods for the resolution of environmental conflicts. Land Use Policy 23, 108-122.

Saaty, T.L., 1990. The Analytic Hierarchy Process: Planning, priority setting, resource allocation. RWS Publications, Pittsburgh.

Sandström, C., Widmark, C., 2007. Stakeholders’ perceptions of consultations as tools for comanagement-A case study of the forestry and reindeer herding sectors in northern Sweden. For. Policy Econ. 10, 25-35.

Sheppard, S.R.J., Meitner, M., 2005. Using multi-criteria analysis and visualisation for sustainable forest management planning with stakeholder groups. For. Ecol. Manag. 207, 171-187.

Starr, M.K., Zeleny, M., 1977. MCDM - State and future of the arts, in: Starr, M.K., Zeleny, M. (Eds.), Multiple Criteria Decision Making. North-Holland Publishing Company, Amsterdam, pp. 5-29.

Webler, T., Tuler, S., Krueger, R.O.B., 2001. What is a good public participation process?

Five perspectives from the public. Environ. Manag. 27, 435-450.

Zeleny, M., 1982. Multiple criteria decision making. McGraw-Hill, New York. 